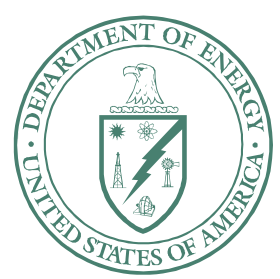

U.S. Department of Energy

Idaho Operations Office

\title{
INL Sitewide Operations and Maintenance Report for CERCLA Response Actions-FY 2005
}

September 2005 
DOE/ID-11249

Revision 0

Project No. 23689

\section{INL Sitewide Operations and Maintenance Report for CERCLA Response Actions-FY 2005}

September 2005

Prepared for the U.S. Department of Energy DOE Idaho Operations Office 



\begin{abstract}
This report documents how remedies mandated by the Comprehensive Environmental Response, Compensation, and Liability Act for the Idaho National Laboratory Site were operated and maintained during fiscal year 2005. The activities addressed in the INEEL Sitewide Operations and Maintenance Plan are reported in this document. Waste Area Groups 7 and 8 are not reported in this document. Waste Area Group 7 is an operating facility, and the status of its operations is reported directly to the regulatory agencies. Waste Area Group 8 is excluded from this report, because it falls outside the direct control of U.S. Department of Energy Idaho Operations Office.
\end{abstract}

The INEEL Sitewide Institutional Controls Plan discusses the inspection, maintenance, repair, and reporting activities involving institutional controls at the Idaho National Laboratory Site. Therefore, the maintenance of institutional controls is not discussed in this report.

The Idaho National Engineering and Environmental Laboratory Comprehensive Facilities and Land Use Plan provides a reference to support this report by providing current and projected facility and land uses and by listing the Comprehensive Environmental Response, Compensation, and Liability Act sites. 


\section{CONTENTS}

ABSTRACT .iii

ACRONYMS vii

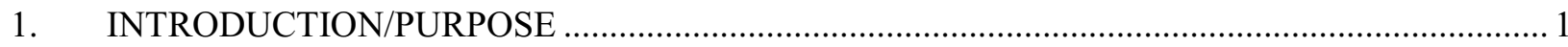

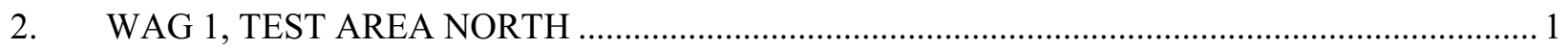

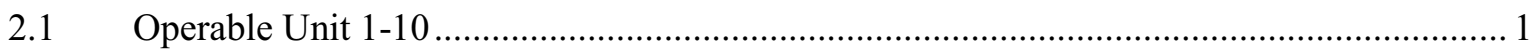

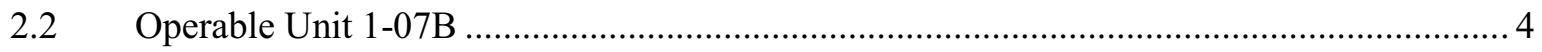

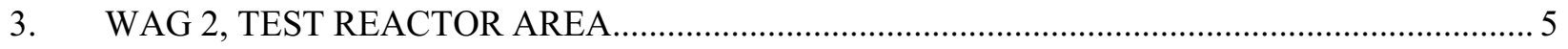

4. WAG 3, IDAHO NUCLEAR TECHNOLOGY AND ENGINEERING CENTER....................... 8

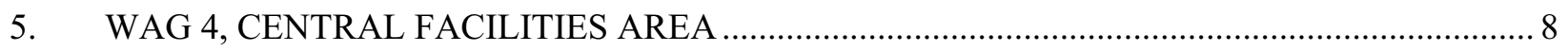

6. WAG 5, AUXILIARY REACTOR AREA/POWER BURST FACILITY/STATIONARY

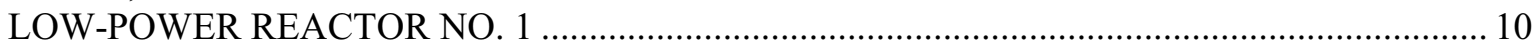

7. WAG 6/10, BOILING WATER REACTOR EXPERIMENT/SITEWIDE CONCERNS .............. 12

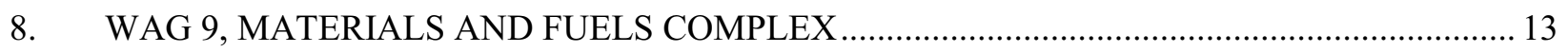

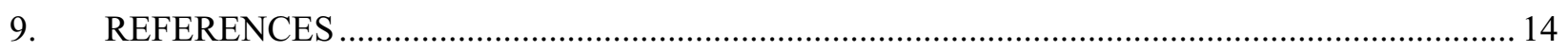

\section{FIGURES}

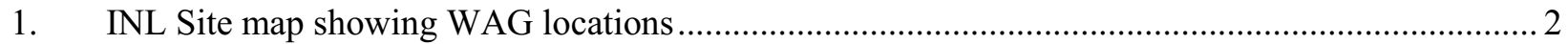

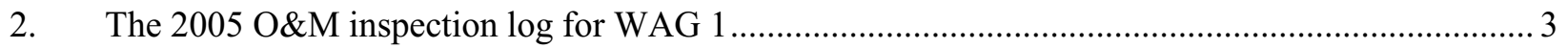

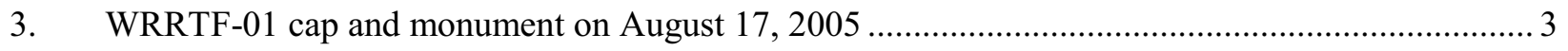

4. Results of radiological survey using the GPRS at TSF-07 in 2005 ............................................ 4

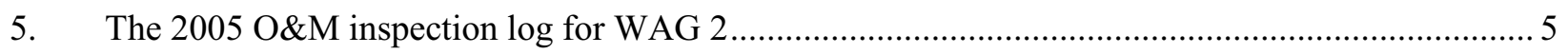

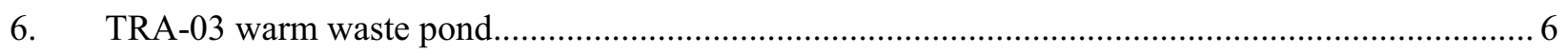

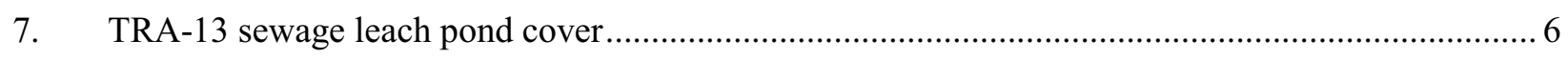

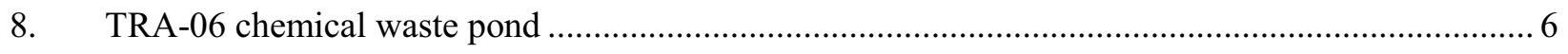

9. Humvee perimeter survey at the TRA-03 warm waste pond in 2005 ........................................... 7 
10. Humvee drive-over survey at the TRA sewage leach pond in 2005 ........................................ 7

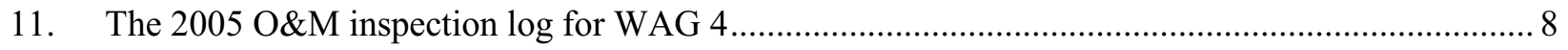

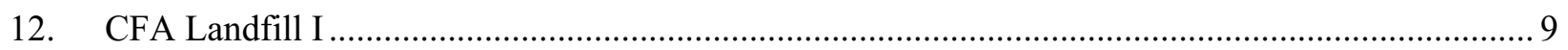

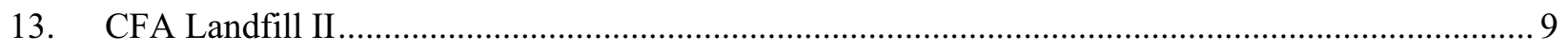

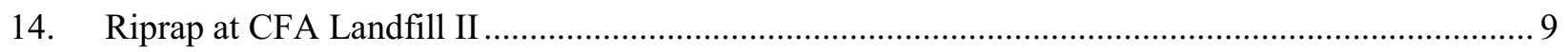

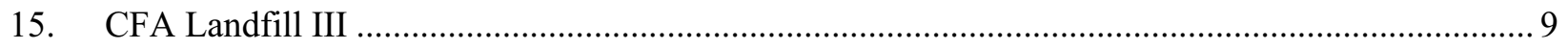

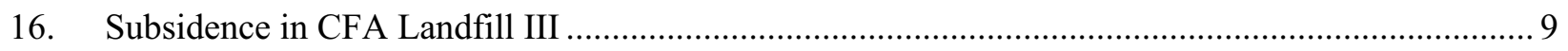

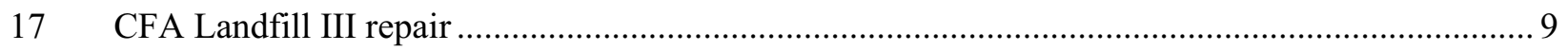

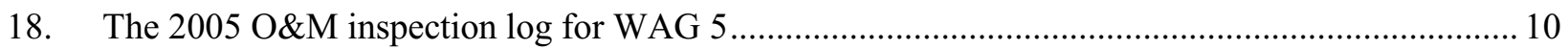

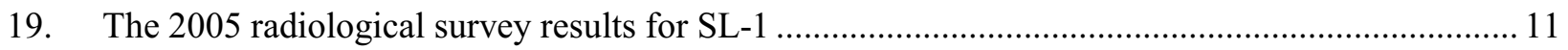

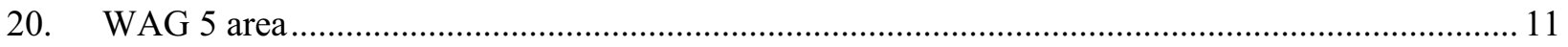

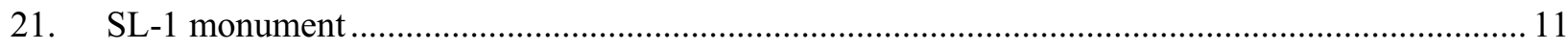

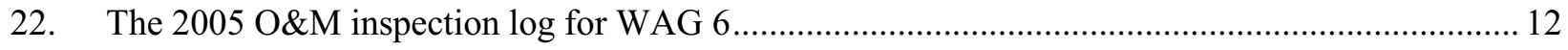

23. The 2005 radiological survey results for the BORAX-02 burial area ........................................ 13

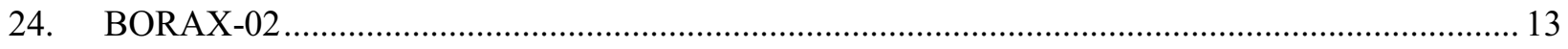

\section{TABLES}

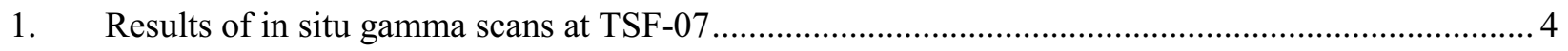




\section{ACRONYMS}

$\begin{array}{ll}\text { ARA } & \text { Auxiliary Reactor Area } \\ \text { BORAX } & \text { Boiling Water Reactor Experiment } \\ \text { CERCLA } & \text { Comprehensive Environmental Response, Compensation, and Liability Act } \\ \text { CFA } & \text { Central Facilities Area } \\ \text { FY } & \text { fiscal year } \\ \text { GPRS } & \text { global positioning radiometric scanner } \\ \text { INL } & \text { Idaho National Laboratory } \\ \text { O\&M } & \text { operations and maintenance } \\ \text { OU } & \text { operable unit } \\ \text { SCA } & \text { soil contamination area } \\ \text { SL-1 } & \text { Stationary Low-Power Reactor No. 1 } \\ \text { TRA } & \text { Test Reactor Area } \\ \text { TSF } & \text { Technical Support Facility } \\ \text { WAG } & \text { waste area group } \\ \text { WRRTF } & \text { Water Reactor Research Test Facility }\end{array}$




\section{INL Sitewide Operations and Maintenance Report for CERCLA Response Actions-FY 2005}

\section{INTRODUCTION/PURPOSE}

This report documents how remedies mandated by the Comprehensive Environmental Response, Compensation, and Liability Act (CERCLA) (42 USC 9601 et seq.) for the Idaho National Laboratory (INL) Site were operated and maintained during fiscal year (FY) 2005. Various records of decision have mandated specific activities intended to ensure that the remedies remain protective of human health and the environment after the remedial activities are completed.

The activities addressed in the INEEL Sitewide Operations and Maintenance Plan for CERCLA Response Actions (DOE-ID 2004a) are reported here. These activities are not the daily operations and maintenance (O\&M) activities associated with operational facilities. Rather, these activities involve the protectiveness and integrity of remedial measures at the INL Site. Results of the annual O\&M inspection are presented for each waste area group (WAG) under the direct control of the U.S. Department of Energy Idaho Operations Office. Therefore, this report excludes WAG 8, the Naval Reactors Facility. In addition, WAG 7, the Radioactive Waste Management Complex, is an operating facility, and the status of its O\&M activities - for example, operation of the vapor vacuum extraction units - is reported directly to the regulatory agencies. See Figure 1 for the location of WAGs at the INL Site.

The INEEL Sitewide Institutional Controls Plan (DOE ID 2004b) discusses the inspection, maintenance, repair, and reporting activities involving institutional controls at the INL Site. Therefore, the maintenance of institutional controls is not discussed in this report.

The Idaho National Engineering and Environmental Laboratory Comprehensive Facilities and Land Use Plan (DOE-ID 1996) provides a reference to support this report by providing current and projected facility and land uses and by listing the CERCLA sites at the INL Site.

\section{WAG 1, TEST AREA NORTH}

\subsection{Operable Unit 1-10}

WAG 1 was visited on August 17, 2005, to conduct the annual O\&M inspection. The WRRTF-01 site within Operable Unit (OU) 1-10 was assessed for soil-cover erosion, subsidence, and intrusion. During remediation in 2004, Pits II and IV at this site received caps. The caps were vegetated in the fall of 2004 , and good growth was observed during the 2005 inspection. No signs of erosion, subsidence, or intrusion were noted. Refer to Figure 2 for the log of the 2005 O\&M inspection activity. Refer to Figure 3 for a photograph of the WRRTF-01 cap and monument.

Environmental monitoring of windblown contamination at the TSF-07 site was performed using the vehicle-based (Humvee) global positioning radiometric scanner (GPRS). Results of the 2005 radiation survey are presented in Figure 4. Refer to Table 1 for a comparison of radiological surveys at TSF-07 over the past five years. Note that the detector configuration changed in November 2003. The count rate from 2004 to 2005 is statistically the same. No migration of contamination was detected at TSF-07. 


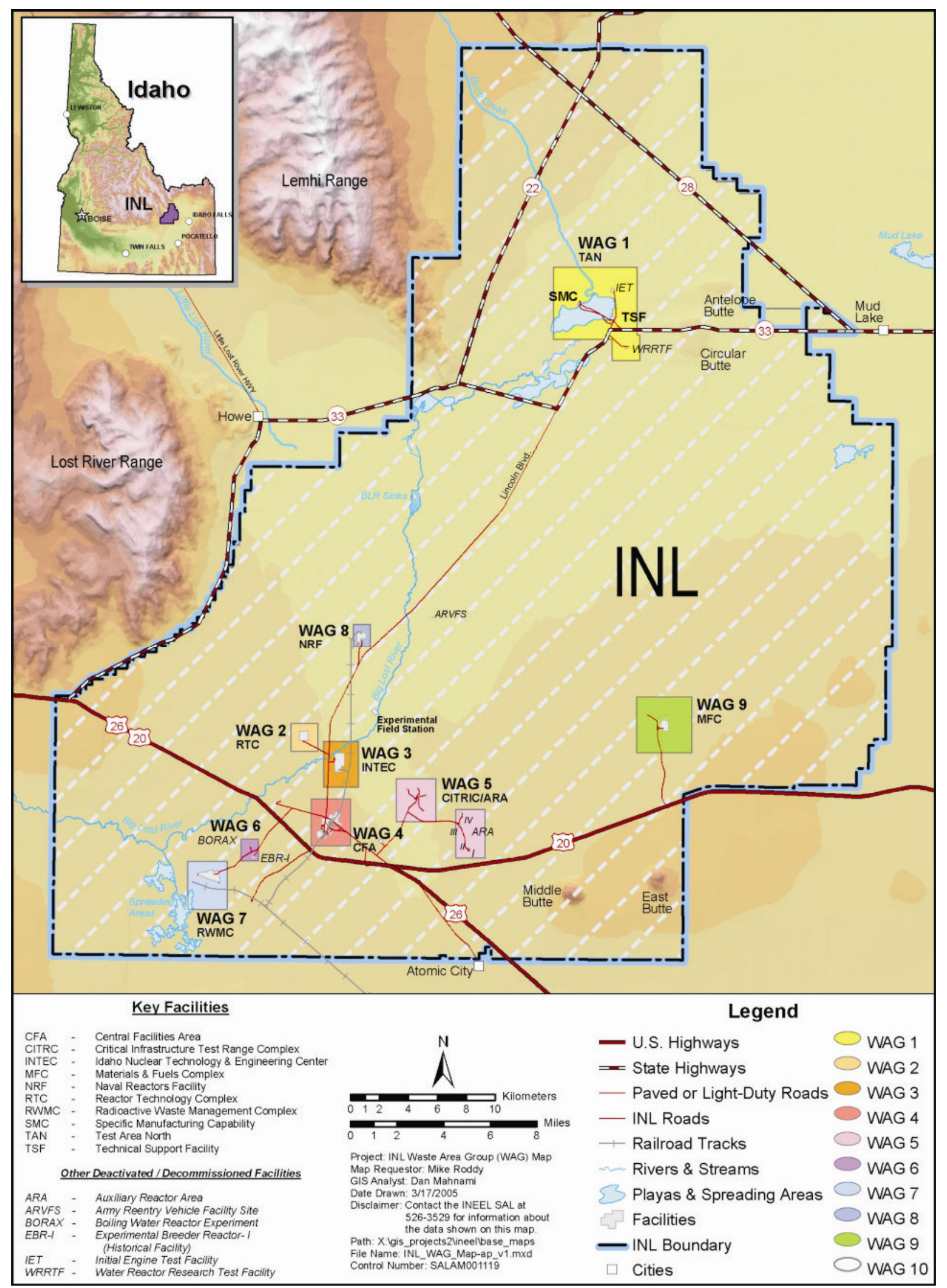

Figure 1. INL Site map showing WAG locations. 


\section{WAG 1 O\&M Inspection Form}

\begin{tabular}{|r|c|c|c|}
\hline WAG 1 & TSF-07 & WRRTF-01 & COMMENTS \\
\hline
\end{tabular}

\section{VEGETATIVE COVER}

\begin{tabular}{|l|l|l|l|}
\hline 1. Inspect for non-growth/sparse growth/weeds. & N/A & Good & Planting of fall 2004 showing good growth, some weed. \\
\hline
\end{tabular}

\section{SOIL COVER}

\begin{tabular}{|l|l|l|l|}
\hline 1. Inspect for erosion areas/animal intrusion. & N/A & None & \\
\hline 2. Inspect for subsidence areas or slope movement. & N/A & None & \\
\hline
\end{tabular}

\section{ENVIRONMENTAL MONITORING (In situ gamma scanner)}

\begin{tabular}{|l|l|l|l|}
\hline 1. Perform annual radiological monitoring & Done & N/A & Humvee scan at perimeter of TSF-07 on 07/18/05 \\
\hline
\end{tabular}

Additional comments or notes:

TSF-06 Area B is not vegetated, and a soil disturbance is in progress to remove piping from TSF-616 to TSF-26. Erosion/subsidence is not an issue in 2005.

TSF-26 has no vegetation. The area is recently remediated and erosion/subsidence is not an issue in 2005.

TSF-09 and TSF-18 are in remediation in 2005. Erosion/subsidence/animal intrusion is not an issue in 2005.

Environmental monitoring was performed at the perimeter of TSF-07 on July 18, 2005. Results show that the area has not changed from previous years and is essentially at background levels.

Inspector (s) _ Renee Fitch_L_ Date_August 17,2005

Figure 2. The 2005 O\&M inspection log for WAG 1.

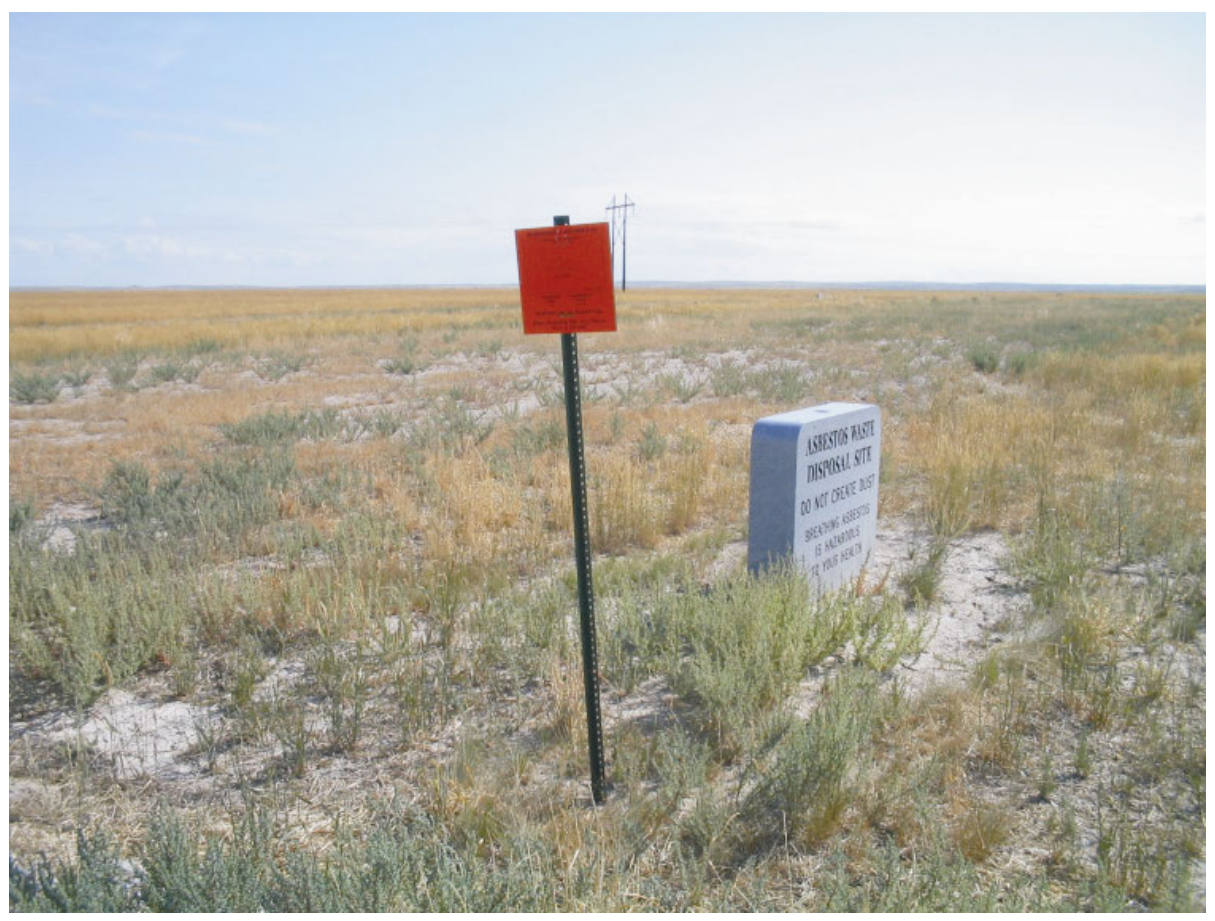

Figure 3. WRRTF-01 cap and monument on August 17, 2005.

(P-2660-12.JPG) 


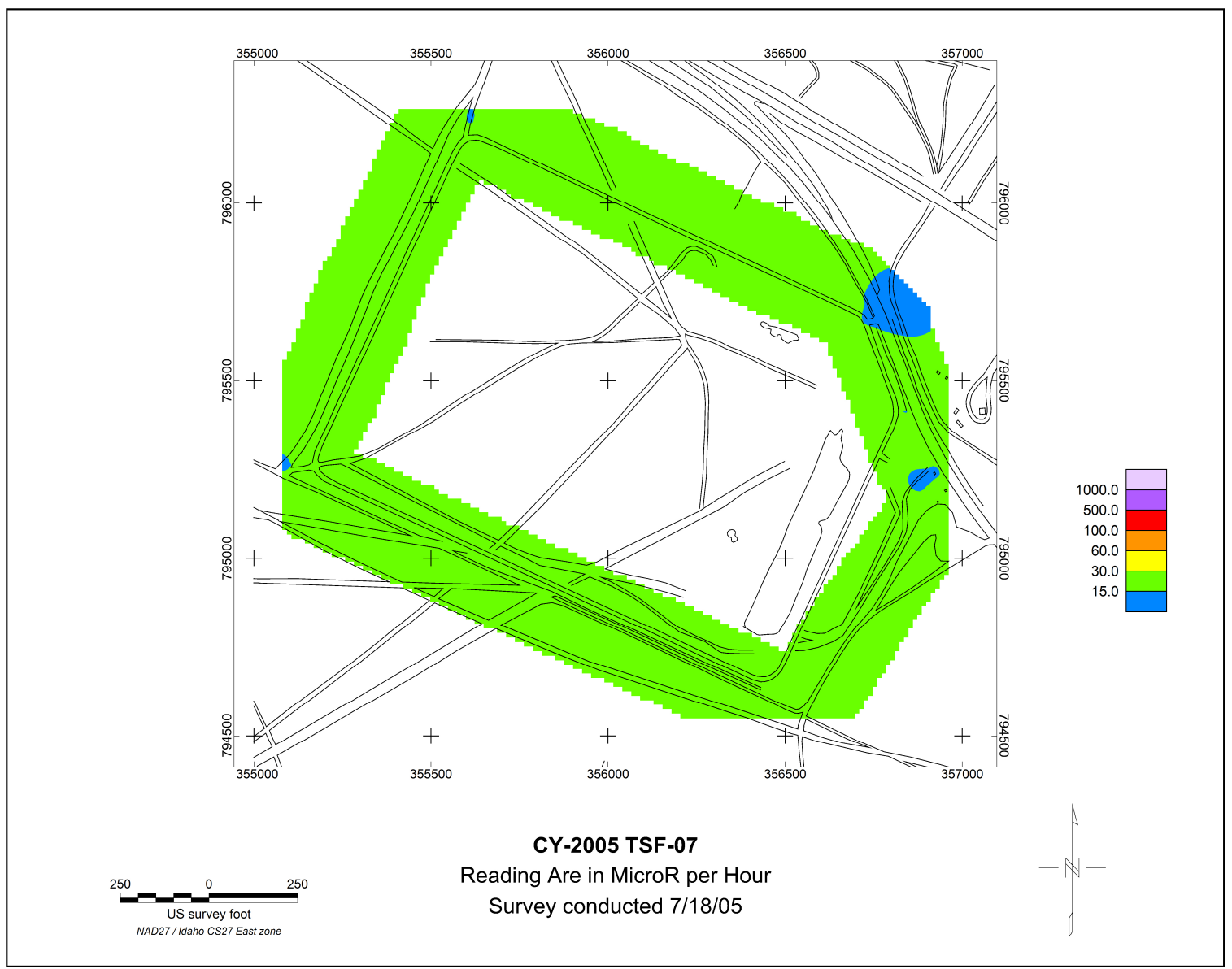

Figure 4. Results of radiological survey using the GPRS at TSF-07 in 2005.

Table 1. Results of in situ gamma scans at TSF-07.

\begin{tabular}{|c|c|c|c|c|}
\hline Year & $\begin{array}{c}\text { Minimum Value } \\
(\text { microR/hr) }\end{array}$ & $\begin{array}{c}\text { Maximum Value } \\
\text { (microR/hr) }\end{array}$ & $\begin{array}{c}\text { Mean Value } \\
\text { (microR/hr) }\end{array}$ & $\begin{array}{c}\text { Standard } \\
\text { Deviation }\end{array}$ \\
\hline 2001 & 5.4 & 15.0 & 12.5 & 2.0 \\
\hline 2002 & 5.2 & 13.4 & 11.3 & 1.35 \\
\hline 2003 & 4.4 & 12.3 & 10.4 & 1.5 \\
\hline 2004 & 10.19 & 22.87 & 20 & 1.67 \\
\hline 2005 & 8.3 & 21.98 & 18.8 & 2.12 \\
\hline
\end{tabular}

\subsection{Operable Unit 1-07B}

O\&M activities at OU 1-07B are ongoing, and the tasks pertain to day-to-day operations. The O\&M activities at the New Pump and Treat Facility are submitted directly to the regulatory agencies in annual operations reports. In the early summer of 2005, operations at the New Pump and Treat Facility ceased and will not resume during 2005. 


\section{WAG 2, TEST REACTOR AREA}

The annual O\&M inspection of WAG 2 sites TRA-03, TRA-06, and TRA-13 and the TRA-13 soil contamination area (SCA) was conducted on August 17, 2005. A visual inspection was performed for subsidence in the covers by walking the perimeters. No evidence of subsidence or erosion was noted. Vegetation was sparse on TRA-06 and TRA-13, with weed growth noted. No evidence of animal intrusion was observed. Refer to Figure 5 for the inspection log. Refer to Figures 6 through 8 for photographs of the sites.

On July 18, 2005, the GPRS (Humvee) radiological surveys were performed around the perimeter at TRA-03 and the TRA-13 SCA and on the cover of TRA-13 SCA. The radiological survey indicated that no change has occurred from previous years. Refer to Figure 9 for results of the radiological survey at TRA-03 and TRA-06. Refer to Figure 10 for the results of the Humvee drive-over at TRA-13 and the TRA-13 SCA.

\section{WAG 2 O\&M Inspection Form}

\begin{tabular}{|c|c|c|c|c|c|}
\hline O\&M INSPECTION ACTIVITY AT TRA & TRA-03 & TRA-06 & TRA-13 & $\begin{array}{c}\text { TRA-13 } \\
\text { SCA } \\
\end{array}$ & COMMENTS \\
\hline \multicolumn{6}{|l|}{ REVEGETATED AREAS } \\
\hline 1. Inspect for non-growth areas. & none & none & none & none & \\
\hline 2. Inspect for non-sparse growth areas. & none & none & none & none & \\
\hline 3. Inspect for weed encroachment. & none & mostly & some & some & Weeds were observed on the noted caps. \\
\hline \multicolumn{6}{|l|}{ NATIVE SOIL COVER } \\
\hline 1. Inspect for erosion areas/animal intrusion. & $\mathbf{N} / \mathbf{A}$ & none & none & none & \\
\hline 2. Insnect for subsidence areas or slope movement. & $\mathbf{N} / \mathbf{A}$ & none & none & none & \\
\hline 3. Conduct topographical survey. & $\mathbf{N} / \mathbf{A}$ & $\mathbf{N} / \mathbf{A}$ & $\mathbf{N} / \mathbf{A}$ & $\mathbf{N} / \mathbf{A}$ & Five-year review only. \\
\hline \multicolumn{6}{|l|}{ PERIMETER OF RADIOLOGICAL SURVEY } \\
\hline 1. Perform perimeter radiological survey. & Done & $\mathbf{N} / \mathbf{A}$ & N/A & N/A & Survey performed on July 18, 2005 \\
\hline \multicolumn{6}{|c|}{ RADIOLOGICAL SURVEY OF SURFACE OF SOLL COVER } \\
\hline 1. Perform surface radiological survey & $\mathbf{N} / \mathbf{A}$ & $\mathbf{N} / \mathbf{A}$ & Done & Done & Surveys performed on July 18,2005 \\
\hline \multicolumn{6}{|l|}{ RIP RAP BARRIER } \\
\hline 1. Inspect for erosion areas. & none & $\mathbf{N} / \mathbf{A}$ & $\mathbf{N} / \mathbf{A}$ & $\mathbf{N} / \mathbf{A}$ & \\
\hline 2. Inspect for subsidence areas. & none & $\mathbf{N} / \mathbf{A}$ & $\mathbf{N} / \mathbf{A}$ & $\mathbf{N} / \mathbf{A}$ & \\
\hline 3. Inspect for biological intrusion. & none & $\mathbf{N} / \mathbf{A}$ & $\mathbf{N} / \mathbf{A}$ & N/A & Rabbits seen on perimeter of cap. \\
\hline 4. Inspect for effectiveness of surface water runoff. & good & N/A & $\mathbf{N} / \mathbf{A}$ & N/A & \\
\hline
\end{tabular}

Additional Comments or Notes:

TRA-03 is the Warm Waste Pond. Perimeter is vegetated. Cover is rip rap. Survey is perimeter only. Vegetation photographed on the cover. TRA-06 is the Chemical Waste Pond and the soil cover shows significant weeds in August 2005

TRA-13 is the Sewage Leach Ponds, and TRA-13-SCA is Soil Contamination Area around the Leach Ponds. Area is capped. Rad survey performed on the perimeter and cover.

Inspector (s) Renee Fitch and Richard Well __

Date August 17, 2005

Figure 5. The 2005 O\&M inspection log for WAG 2. 


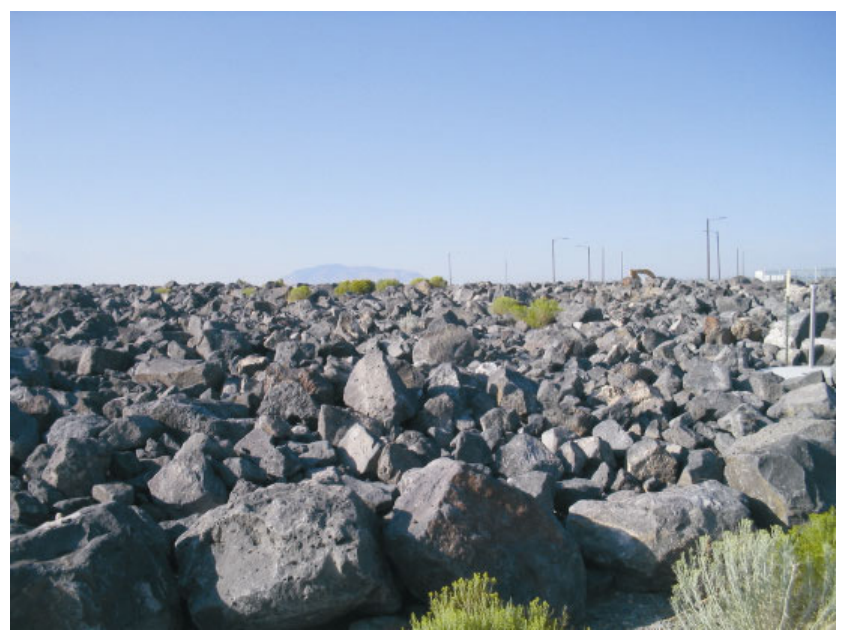

Figure 6. TRA-03 warm waste pond. $\quad$ (P-2660-03.JPG)

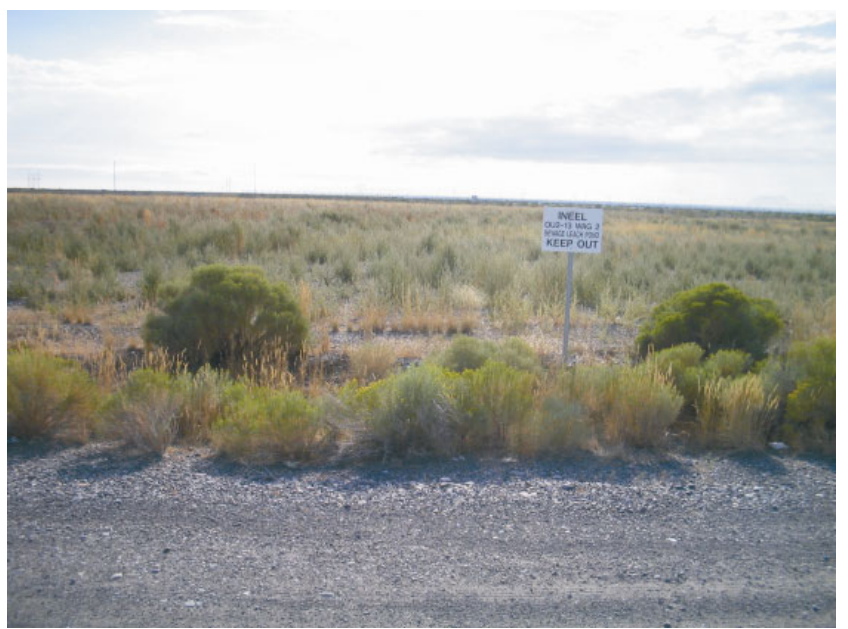

Figure 7. TRA-13 sewage leach pond cover. (P-2660-01.JPG)

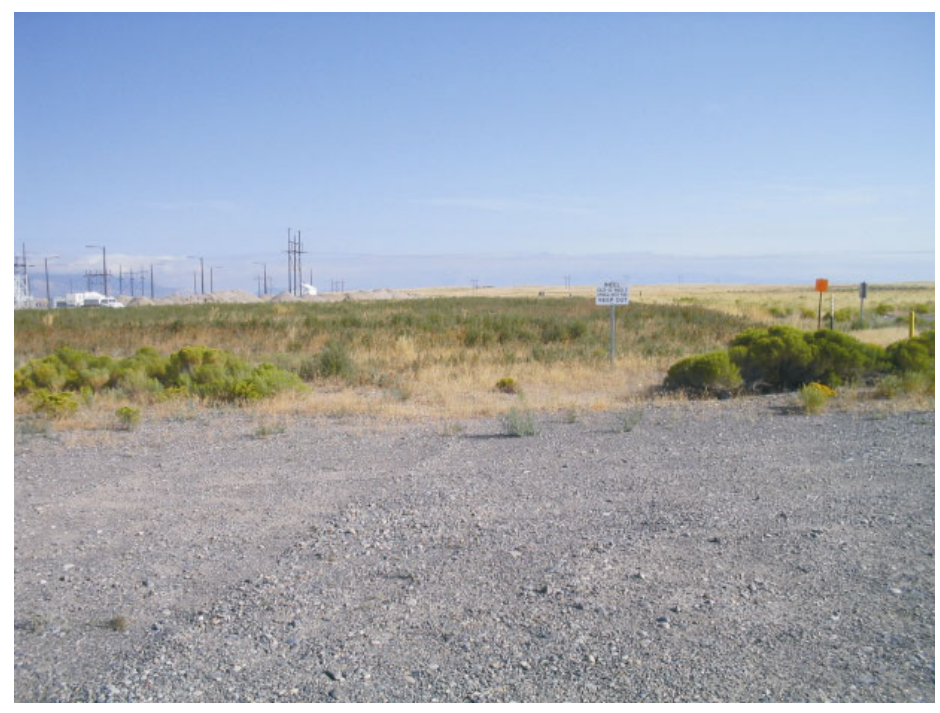

Figure 8. TRA-06 chemical waste pond. (P-2660-08.JPG) 


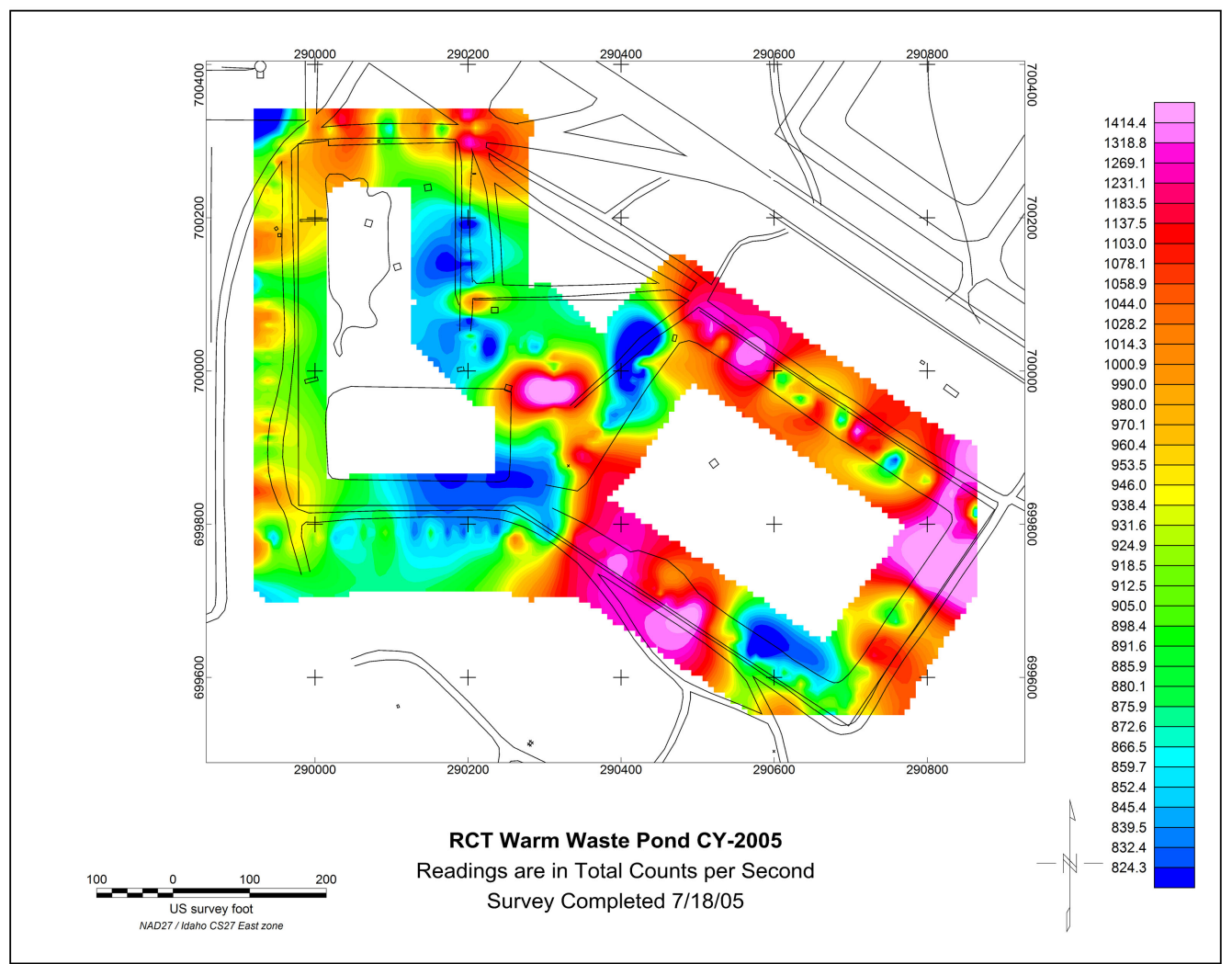

Figure 9. Humvee perimeter survey at the TRA-03 warm waste pond in 2005.

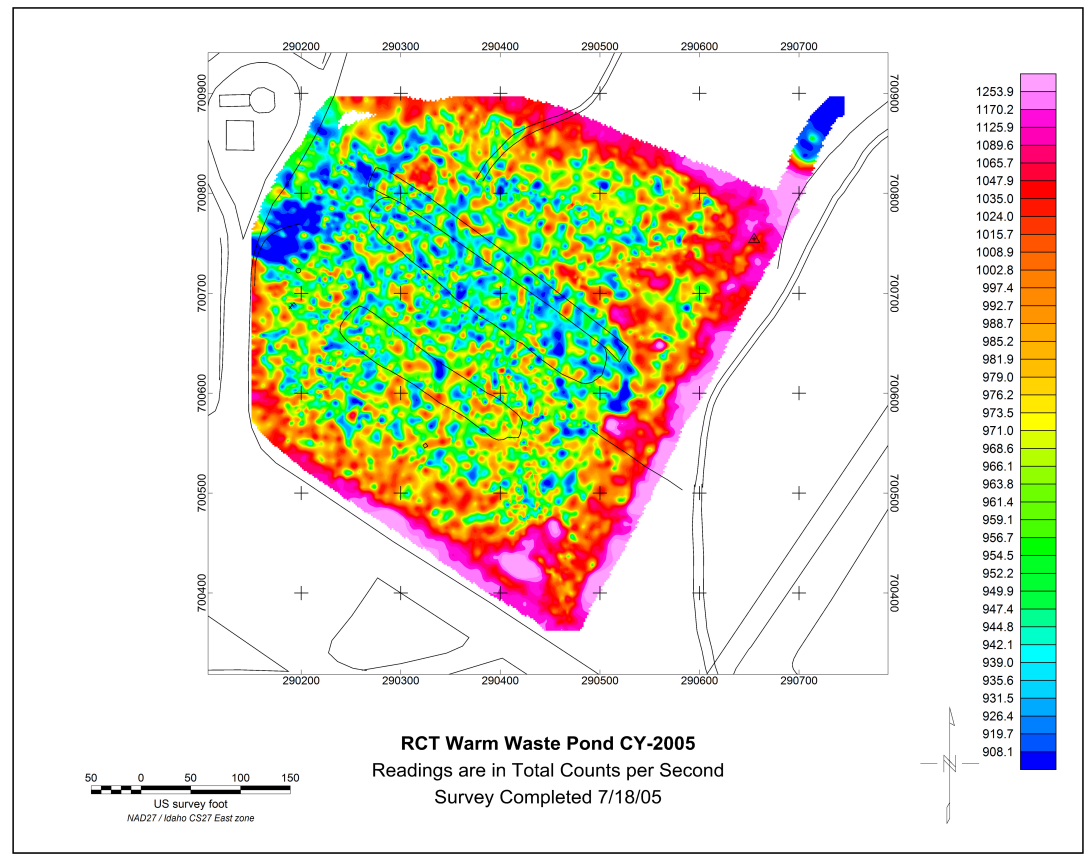

Figure 10. Humvee drive-over survey at the TRA sewage leach pond in 2005. 


\section{WAG 3, IDAHO NUCLEAR TECHNOLOGY AND ENGINEERING CENTER}

WAG 3 is subject to the Final Record of Decision-Idaho Nuclear Technology and Engineering Center, Operable Unit 3-13 (DOE-ID 1999). Currently, no CERCLA O\&M activities are defined at WAG 3. Tank farm inspections are required but are currently reported in a separate report. As remedial activities evolve at WAG 3, O\&M requirements will be reevaluated.

\section{WAG 4, CENTRAL FACILITIES AREA}

On August 17, 2005, O\&M sites at WAG 4 were inspected: CFA-01, CFA-02, CFA-03, and CFA-08. These sites are inspected annually for erosion, animal intrusion, subsidence, and the condition of the soil covers and vegetative cover. Additionally, CFA-08 is inspected for the condition of the monuments, and the three landfill sites are inspected for the condition of monitoring equipment and rock armor as applicable. The 2005 O\&M inspection showed no evidence of subsidence, erosion, or intrusion. Vegetation is in good condition on the Central Facilities Area (CFA) landfills, and the subsidence area reported in 2004 at CFA Landfill III has been repaired.

Refer to Figure 11 for the 2005 O\&M inspection log for WAG 4. Refer to Figures 12 through 15 for photographs of the CFA landfill area. Refer to Figures 16 and 17 for photographs of the subsidence area before and after it was repaired.

WAG 4 O\&M Inspection Form

\begin{tabular}{|c|c|c|c|c|}
\hline INSPECTION ACTIVITY AT LANDFILLS & CFA-01 & CFA-02 & CFA-03 & COMMENTS \\
\hline \multicolumn{5}{|l|}{ VEGETATIVE COVER } \\
\hline 1. Inspect for non-growth/sparse growth/weeds. & none & none & none & \\
\hline \multicolumn{5}{|l|}{ SOIL COVER } \\
\hline 1. Inspect for erosion areas/animal intrusion. & none & none & none & \\
\hline 2. Inspect for subsidence areas or slope movement. & none & none & none & \\
\hline 3. Conduct topographical survey. & none & none & none & Visual except during 5-year review. \\
\hline \multicolumn{5}{|l|}{ TIME DOMAIN REFLECTOMETER (TDR) } \\
\hline 1. Inspect cabinet interior for unusual dirt or debris. & N/A & done & done & \\
\hline $\begin{array}{l}\text { 2. Inspect exterior and interior of cabinet for deterioration } \\
\text { and presence of moisture or water. }\end{array}$ & N/A & done & done & \\
\hline 3. Inspect solar collector barrel for condition/function. & N/A & done & done & \\
\hline $\begin{array}{l}\text { 4. Inspect and verify presence of guard post and/or } \\
\text { impingement posts. }\end{array}$ & N/A & present & present & \\
\hline \multicolumn{5}{|c|}{ SOIL GAS WELLS and NEUTRON PROBE ACCESS TUBES (NPATs) } \\
\hline 1. Inspect for integrity/cleanliness. & N/A & goof & goof & \\
\hline 3. Inspect, rust on cover, well casing damage. & N/A & none & none & \\
\hline 4. Inspect guara posts around weil cover. & $\mathbf{N} / \mathbf{A}$ & present & present & \\
\hline \multicolumn{5}{|l|}{ ROCK ARMOR } \\
\hline $\begin{array}{l}\text { 1. Inspect to verify no more than } 12 \text { inches of subsidence of } \\
\text { rock armor. }\end{array}$ & N/A & none & N/A & . \\
\hline 2. Conduct topographical survey. & N/A & N/A & N/A & During 5-year review. \\
\hline
\end{tabular}

Figure 11. The 2005 O\&M inspection log for WAG 4. 


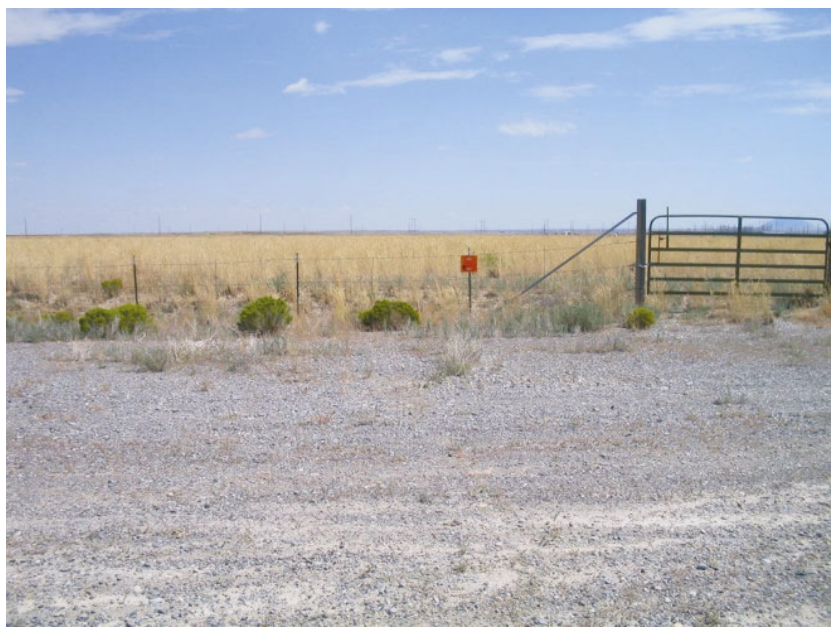

Figure 12. CFA Landfill I.

(P-2660-14.JPG)

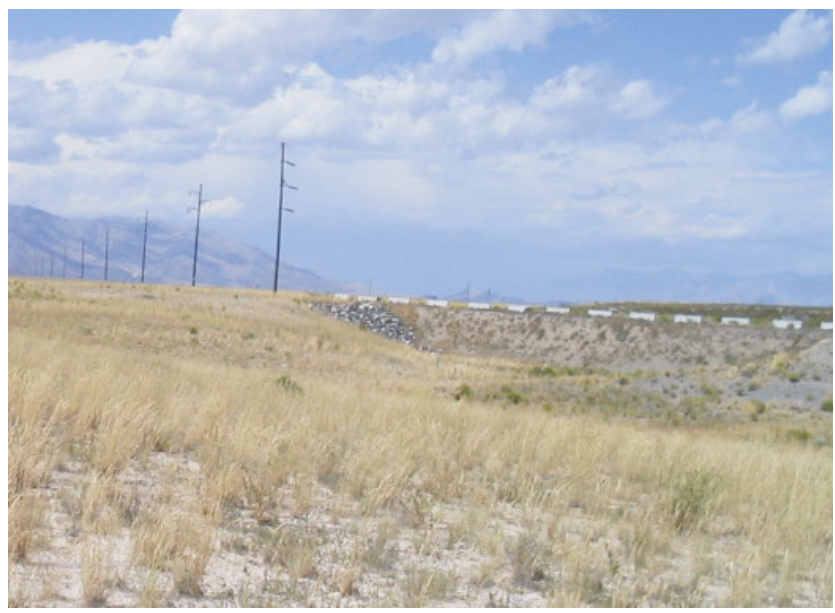

Figure 14. Riprap at CFA Landfill II. $\quad$ (P-2660-18.JPG)

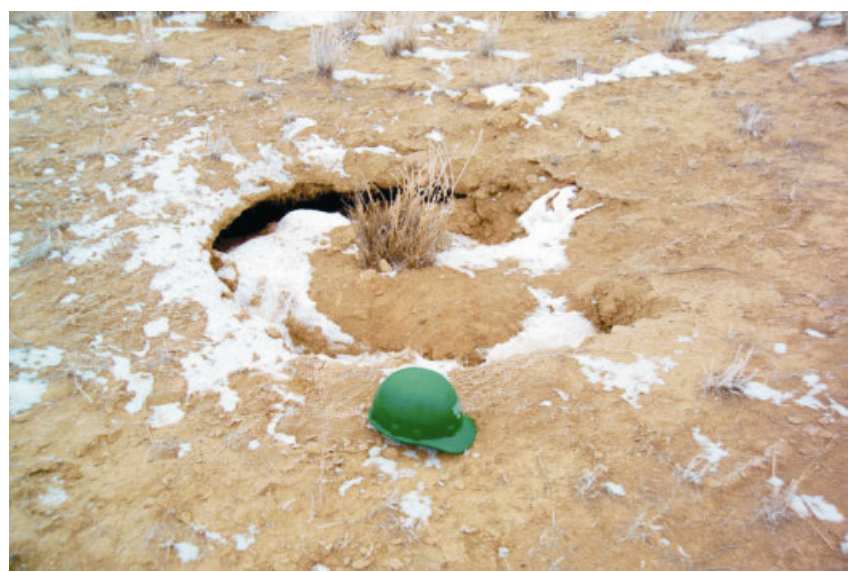

Figure 16. Subsidence in CFA Landfill III. (P-1216-06.JPG)

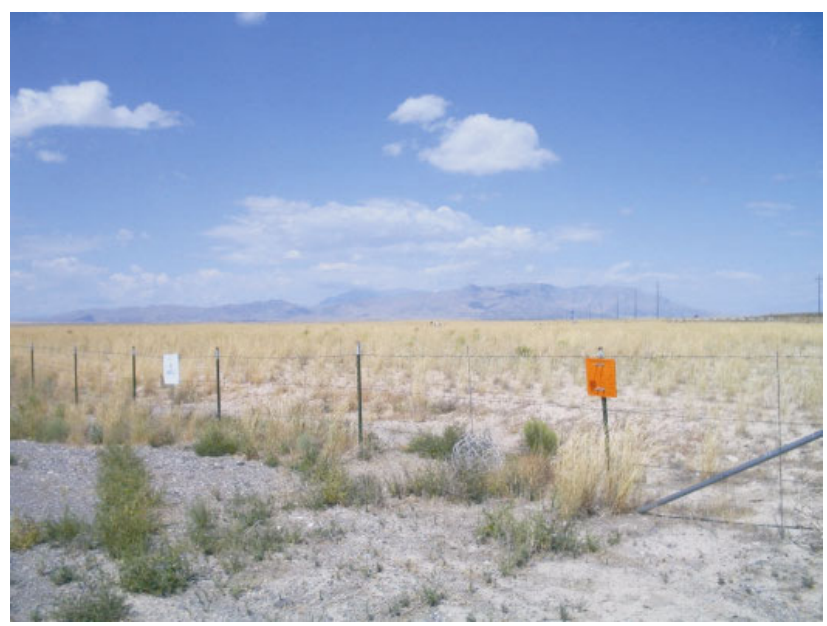

Figure 13. CFA Landfill II.

(P-2660-13.JPG)

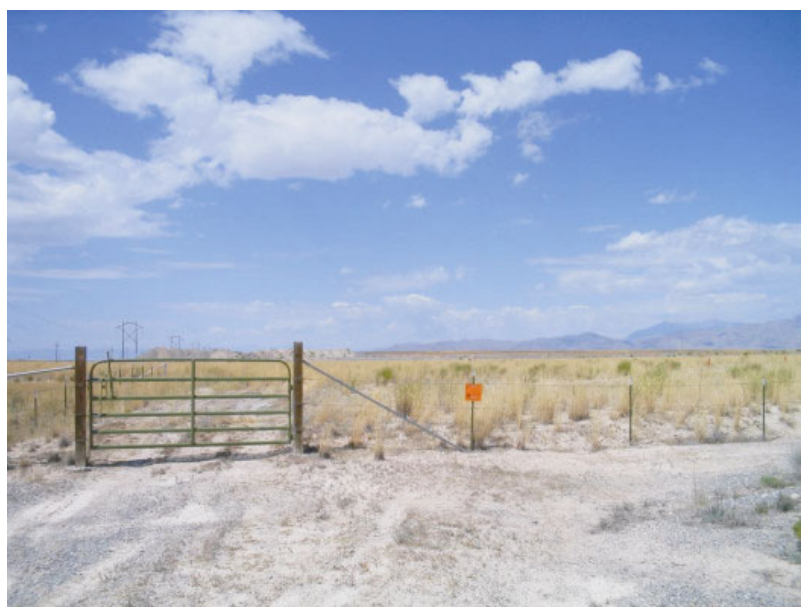

Figure 15. CFA Landfill III.

(P-2660-15.JPG)

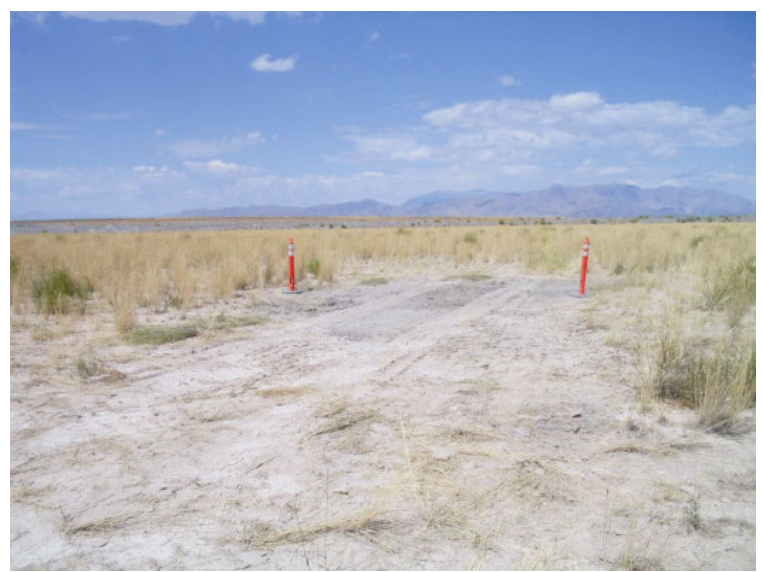

Figure 17. CFA Landfill III repair. $\quad$ (P-2660-16.JPG) 


\section{WAG 5, AUXILIARY REACTOR AREA/POWER BURST FACILITYISTATIONARY LOW-POWER REACTOR NO. 1}

The annual WAG 5 O\&M inspection was conducted on August 17, 2005. No deficiencies were observed. Growth of the recently planted vegetation on the areas remediated in 2004 was good. The radiological survey indicated conditions have not changed from 2004.

Refer to Figure 18 for the site inspection log. Refer to Figure 19 for the 2005 radiological survey report for the Stationary Low-Power Reactor No. 1 (SL-1), i.e., the ARA-06 site. Refer to Figures 20 and 21 for photographs of WAG 5 and the SL-1 burial ground.

\section{WAG 5 O\&M Inspection Form}

\begin{tabular}{|l|c|c|c|}
\hline \multicolumn{1}{|c|}{ ARA } & ARA-23 & ARA-25 & COMMENTS \\
\hline 1. Inspect for intrusion. & none & none & \\
\hline 2. Inspect for subsidence areas or slope movement. & none & none & \\
\hline 3. Inspect for erosion. & none & none & \\
\hline 4. Inspect vegetative cover when applicable. & good & good & Recent vegetation is growing well due to spring rains. \\
\hline
\end{tabular}

\begin{tabular}{|l|c|c|}
\hline \multicolumn{1}{|c|}{ SL-1 Burial Ground } & ARA-06 & COMMENTS \\
\hline BIOTIC BARRIER & none & \\
\hline 1. Inspect for erosion and intrusion & none & \\
\hline 2. Inspect cover for settling and erosion. & \\
\hline
\end{tabular}

\section{RIP RAP BARRIER}

\begin{tabular}{|l|l|l|}
\hline 1. Inspect for erosion and intrusion & none & \\
\hline 2. Inspect cover for settling and erosion. & none & \\
PERIMETER OF RADIOLOGICAL SURVEY & done & Performed on August 11, 2005 \\
\hline 1. Perform perimeter radiological survey. &
\end{tabular}

Comment or notes

There are no O\&M inspection activities at PBF. ARA-01, ARA-02, ARA-12 and ARA-16 not longer require inspection. Results of perimeter radiological survey are consistent with previous years.

Inspector (s)

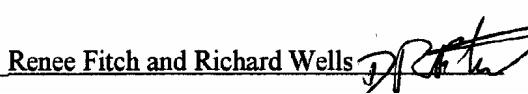

Date June 14, 2005

Figure 18. The 2005 O\&M inspection log for WAG 5. 


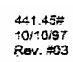

RADIOLOGICAL SURVEY REPORT

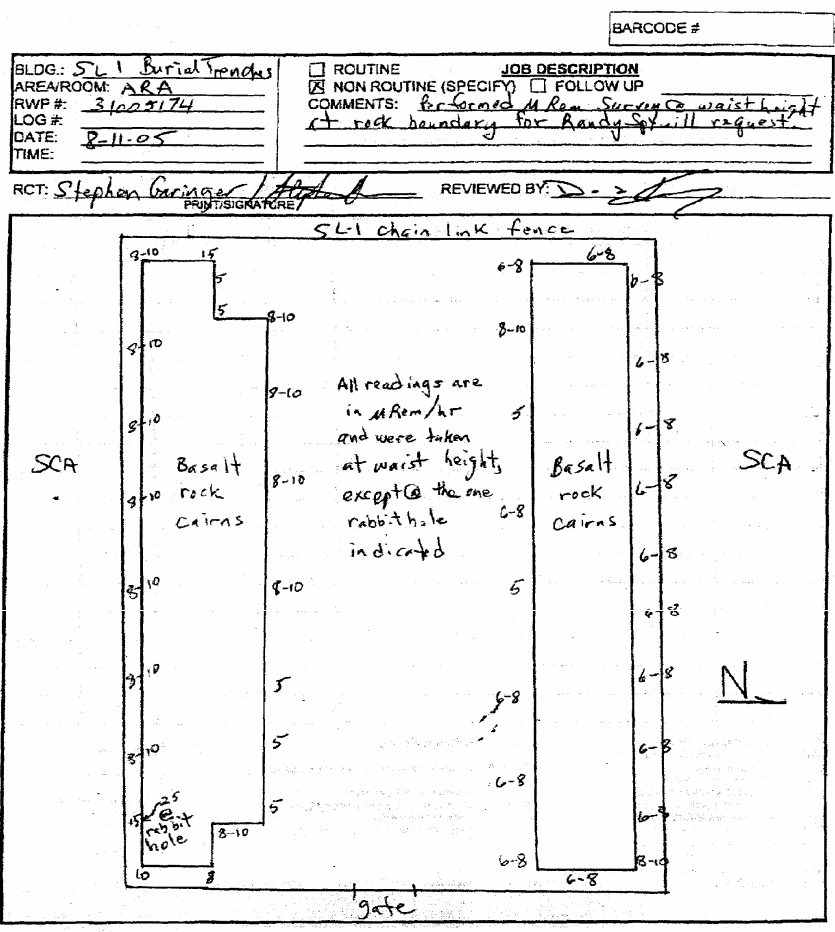

$\underset{\substack{77 \\ 33}}{4}$

RADIOLOGICAL SURVEY REPORT

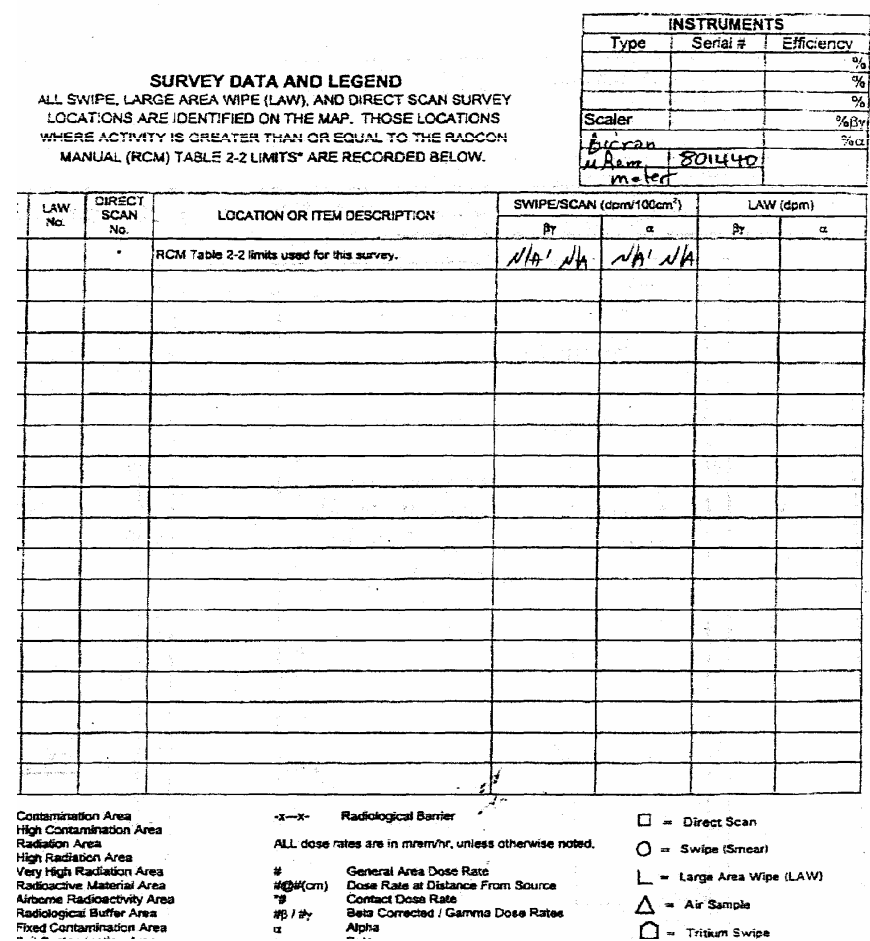

Figure 19. The 2005 radiological survey results for SL-1.

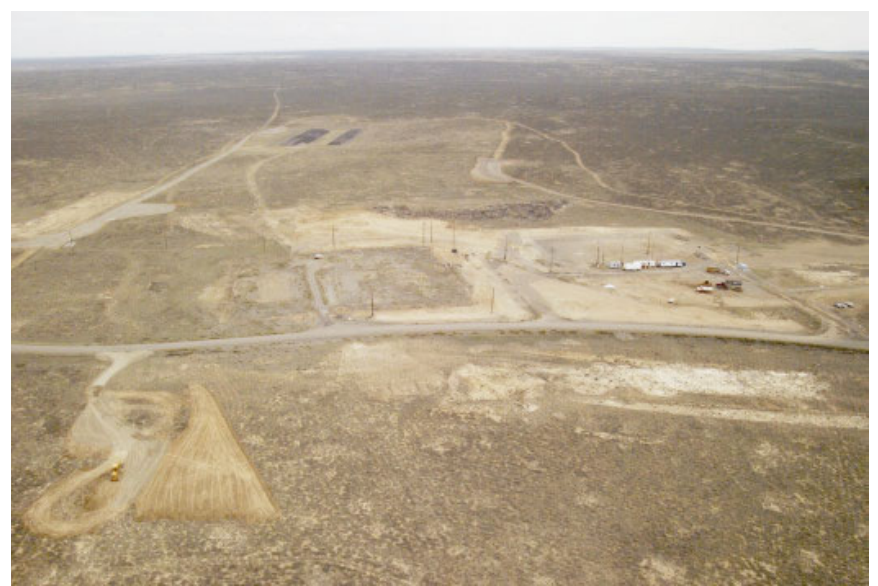

Figure 20. WAG 5 area.
(PD040079-130.jpg)

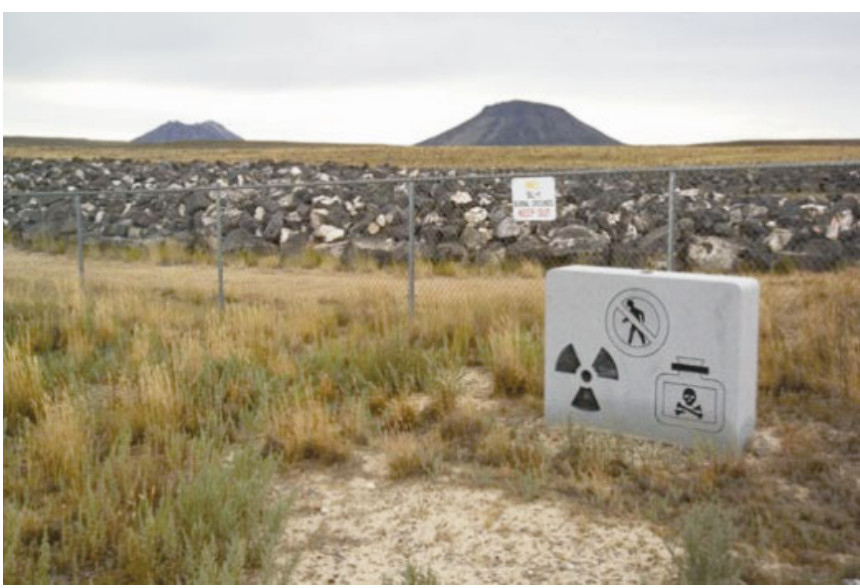

Figure 21. SL-1 monument.

(PD040213-01.jpg) 


\section{WAG 6/10, BOILING WATER REACTOR EXPERIMENT/SITEWIDE CONCERNS}

The Boiling Water Reactor Experiment (BORAX) I burial ground, i.e., the BORAX-02 site, was inspected on June 14, 2005. The perimeter radiological survey was performed at BORAX-02 on August 11, 2005. No subsidence or erosion was noted, and the radiological results were consistent with previous years. Refer to Figure 22 for the 2005 site inspection log. Refer to Figure 23 for the results of the radiological survey. Refer to Figure 24 for a photograph of BORAX-02.

\section{WAG 6 O\&M Inspection Form}

\begin{tabular}{|l|c|c|}
\hline BORAX Burial Ground & BORAX 02 & COMMENTS \\
\hline
\end{tabular}

\section{RIP RAP BARRIER}

\begin{tabular}{|l|l|l|}
\hline 1. Inspect for erosion and intrusion & None & \\
\hline 2. Inspect cover for settling and erosion. & None & \\
\hline
\end{tabular}

PERIMETER OF RADIOLOGICAL SURVEY

\begin{tabular}{|l|l|l|}
\hline 1. Perform perimeter radiological survey. & Done & \\
\hline
\end{tabular}

Comment or notes.

RadCon performed the survey at this site on August 11,2005. All results consistent with previous year.

Condition of the fence and monuments was good. No sign of intrusion.

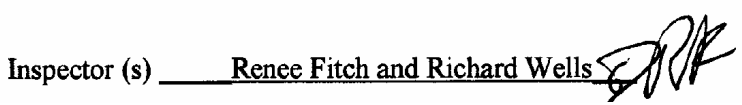

Date June 14,2005

Figure 22. The 2005 O\&M inspection log for WAG 6 . 

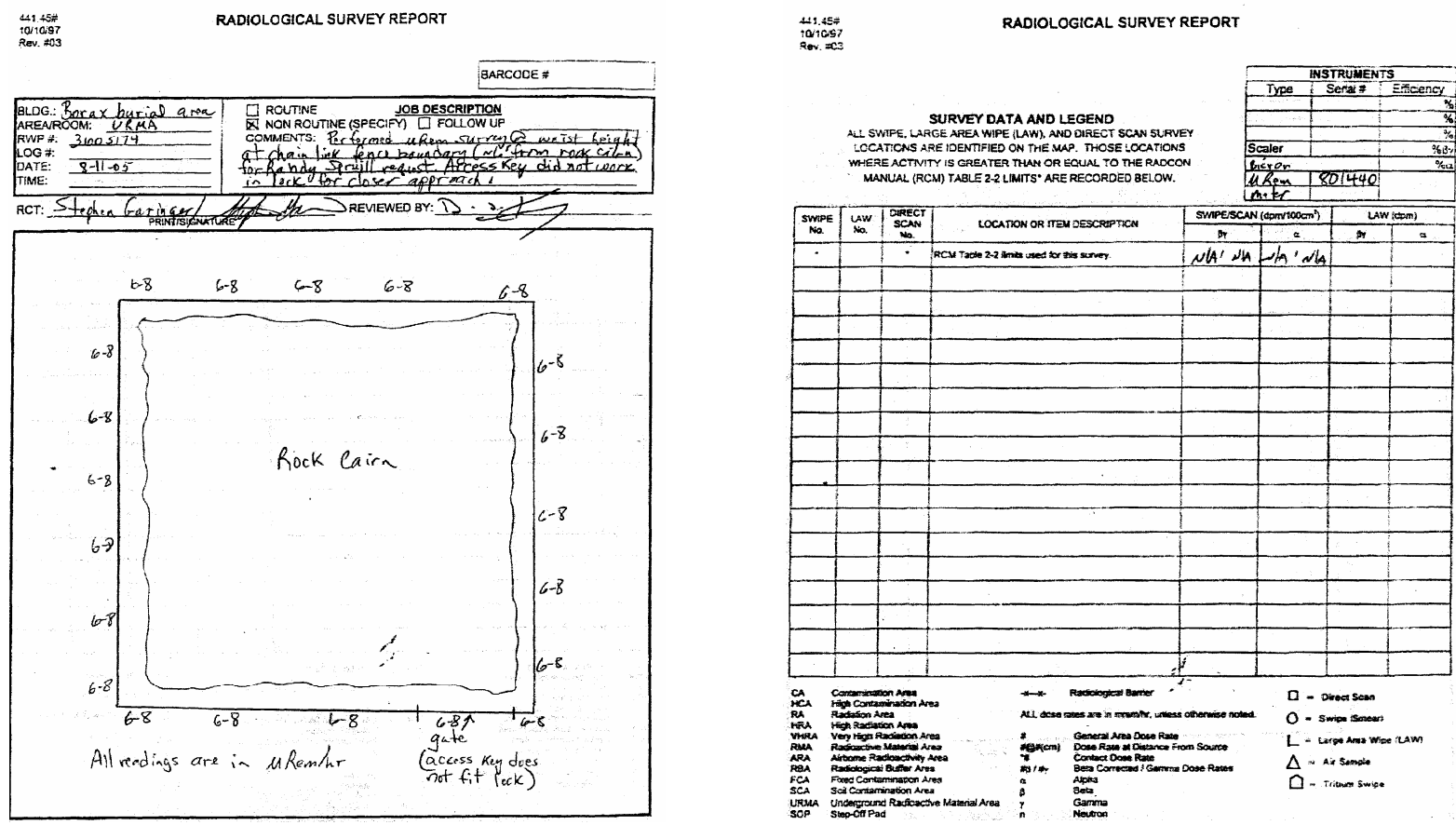

Figure 23. The 2005 radiological survey results for the BORAX-02 burial area.

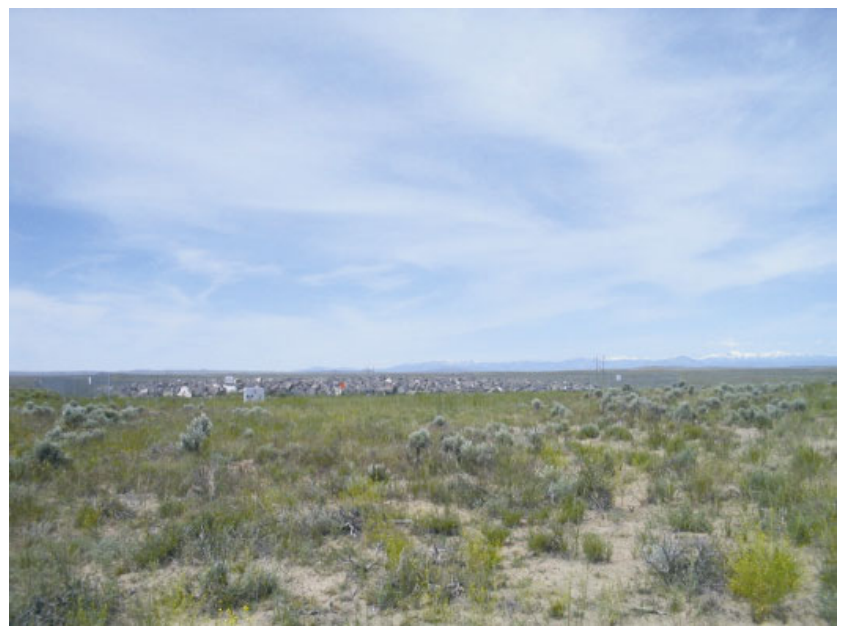

Figure 24. BORAX-02.

P-2612-14.JPG

\section{WAG 9, MATERIALS AND FUELS COMPLEX}

Currently, two CERCLA sites at the Material and Fuels Complex require O\&M reporting. These areas are the industrial waste pond (ANL-01) and the interceptor canal (ANL-09). The ANL-09 site has been further subdivided into the interceptor canal-ditch and the interceptor canal-mound because of the distinct differences in the soil in the ditch and the dredged and stockpiled soil of the mound. These three areas have radiological contamination from Cs-137. The contamination level is below action levels but greater than background levels. All three sites have institutional controls in place; specifically, warning signs are visible around the site perimeters. The interceptor canal-mound and the area above the high-water mark in the industrial waste pond were seeded in the fall of 2004 and are scheduled for 
inspection in October 2005. The interceptor canal-canal was not revegetated, because it continues to be used to convey rain and snowmelt from a 14- $\mathrm{mi}^{2}$ area south of the Materials and Fuels Complex to the industrial waste pond. A report of this inspection will be included in the 2006 O\&M report.

Additionally, the sanitary sewage lagoon (ANL-04) is a CERCLA site that presents an ecological risk due to mercury levels in the sludge. The remediation of this site has been transferred to OU 10-08. Final remediation will be conducted after the useful life of the sanitary sewage lagoons, which is anticipated to be 2033. If the OU 10-08 baseline risk assessment shows that the human and ecological risks are acceptable, remediation might not be required. Currently, the risk from the mercury is mitigated by ensuring that the liquid level in the lagoon covers the sludge. This eliminates the exposure pathway to the small burrowing mammals. In 2005, the liquid level was inspected by the Argonne National Laboratory-West environmental monitoring staff during collection of the liquid effluent samples. The liquid level at ANL-04 was found to be protective in 2005.

\section{REFERENCES}

42 USC 9601 et seq., 1980, "Comprehensive Environmental Response, Compensation and Liability Act of 1980," United States Code, December 11, 1980.

DOE-ID, 1996, Idaho National Engineering and Environmental Laboratory Comprehensive Facility and Land Use Plan, DOE/ID-10514, Rev. 0, U.S. Department of Energy Idaho Operations Office, March 1996. (NOTE: This version contains official use only information. It is available internally at http://meris.inel.gov. An unclassified version, DOE/ID-10514-97, is available at http://cflup.inel.gov for external access.)

DOE-ID, 1999, Final Record of Decision-Idaho Nuclear Technology and Engineering Center, Operable Unit 3-13, DOE/ID-10660, Rev. 0, U.S. Department of Energy Idaho Operations Office, October 1999.

DOE-ID, 2004a, INEEL Sitewide Operations and Maintenance Plan for CERCLA Response Actions, DOE/NE-ID-11159, Rev. 0, U.S. Department of Energy Idaho Operations Office, September 2004.

DOE-ID, 2004b, INEEL Sitewide Institutional Controls Plan, DOE/ID-11042, Rev. 1, U.S. Department of Energy Idaho Operations Office, June 2004. 